\title{
Moniluonnontieteellinen Globe-ympäristökasvatusprojekti
}

\author{
Laura Riuttanen \\ Fysiikan laitos, Helsingin yliopisto \\ Taina Ruuskanen \\ Fysiikan laitos, Helsingin yliopisto
}

\begin{abstract}
Abstrakti GLOBE on toiminnallinen ympäristötiede ja -kasvatusohjelma, jossa opiskelijat, opettajat ja tutkijat ympäri maailman tutkivat yhdessä ympäristöä sekä paikallisella että globaalilla tasolla. GLOBE-ohjelman tavoitteena on lisätä ihmisten ympäristötietoisuutta kaikkialla maailmassa, myötävaikuttaa maapalloa koskevan tieteellisen ymmärryksen lisääntymiseen sekä parantaa luonnontieteiden ja matematiikan opiskelun tasoa. GLOBE sopii kaikille kouluasteille alakoulusta lukioon.
\end{abstract}

\section{Tausta}

GLOBE-ohjelma on lähtöisin Yhdysvalloista ja siihen osallistuu tuhansia kouluja yli sadassa eri maassa. GLOBE-opiskelijat ovat kirjanneet ylös miljoonia ilmakehää, hydrologiaa, maan peittoisuutta ja biologiaa sekä maaperää koskevaa tieteellistä havaintoa ja mittausta. Suomessa GLOBE-toiminta alkoi 1990-luvulla, jolloin ohjelmassa oli mukana yli sata koulua. Tällä hetkellä aktiivisia GLOBE-kouluja on kymmenkunta, mutta toiminta on viriämässä uudelleen Viikin Normaalikoulun ja Helsingin yliopiston Ilmakehätieteiden osaston koordinoimana Opetushallituksen tuella.

GLOBE-opiskelijat tekevät säännöllisiä ympäristöhavaintoja ja -mittauksia koulun lähiympäristössä. Suomen GLOBE-kouluissa on perehdytty erityisesti säämittauksiin. Opiskelijat ilmoittavat tuloksensa Internetin välityksellä GLOBE-tietokeskukseen, josta ne ovat kaikkien GLOBE-opiskelijoiden saatavilla. Maailmanlaajuisista mittaustietokannoista opiskelijat voivat sitten tehdä omia tutkimuksiaan, esimerkiksi vertailla oman koulun mittaustuloksia toisella puolella maailmaa olevan koulun vastaaviin mittauksiin. GLOBE tuottaa paljon myös valmiita materiaaleja globaalien ympäristöasioiden opiskeluun.

Kansainvälisyys on olennainen osa GLOBE-ohjelmaa. Opiskelijat toimivat vuorovaikutuksessa eri puolilla maapalloa asuvien GLOBE-opiskelijoiden kanssa. Ympäristötieteellinen tiedeyhteisö osallistuu GLOBE-ohjelman suunnitteluun ja käytännön toteutukseen varmistamalla, että opiskelijoiden tekemät ympäristömittaukset ovat globaalin ympäristön perustutkimuksen kannalta tarkoituksenmukaisia. Eri puolilta maailmaa tulevat tutkijat ottavat osaa GLOBE:n tieteellisten mittausten valitsemiseen, mittausmenetelmien kehittämiseen ja varmistavat kerätyn aineiston laadun. Suomessa erityisesti Helsingin yliopiston Fysiikan laitos on ollut luomassa yhteyksiä GLOBEverkostoon.

Kansainvälinen ympäristökasvattajien ryhmä on laatinut GLOBE:n opetuskokonaisuuden tehtävineen. Sen tarkoituksena on sekä opastaa opiskelijoita omien 
mittausten ja havaintojen tekemisessä että auttaa heitä ymmärtämään niiden avulla karttuvan lähiympäristön tilaa kuvaavan aineiston merkitys ja liittyminen koko maapallonlaajuisiin systeemeihin.

GLOBE-opettajat osallistuvat koulutukseen, jossa opiskellaan ohjelman mittausten ja havaintojen ja käytännön toteuttamista, tietoverkon monipuolista käyttämistä sekä GLOBE-materiaalien ottamista osaksi luonnontieteiden ja matematiikan opetusta omassa koulussa.

\section{GLOBE Suomessa tapahtuu}

Maaliskuusta 2013 Suomen GLOBE-maakoordinaattorina on toiminut fysiikan yliopistonlehtori Taina Ruuskanen Helsingin yliopistolta. Hän osallistui keväällä 2013 GLOBE Euroopan tapaamiseen Tallinnassa ja tutustui uudistuneisiin GLOBE verkkosivuihin (www.GLOBE.gov). Helsingin yliopistolla Taina tutkii metsien vaikutusta ilmakehää viilentävien aerosolihiukkasten muodostumisessa ja järjestää koulutus- ja kehittämiskeskus Palmenian kanssa täydennyskoulutusta opettajille. Elokuussa 2013 Hyytiälän metsäasemalla järjestettiin GLOBE-aiheisiinkin perehdyttävä kurssi "Rakenna oma sääasema”. Kurssilaiset perehtyivät sään havainnoimiseen ja asensivat ryhmissä omat sääasemat. Yhdessä mittailtaessa opittiin, mitä kaikkea säämittauksissa pitää ottaa huomioon ja havaittiin muun muassa ilman kuuman tasakaton yllä lämpenevän ja jäähtyvän hitaammin kuin mittauspisteessä nurmikentän yllä. Kurssi järjestetään uudestaan kesällä 2014.

Marraskuussa 2013 ja tammikuussa 2014 pidetään "Meteorologian perusteet"-kurssi, joka mahdollistaa tutustumisen sääjärjestelmiin. Kurssi järjestettiin ensimmäisen kerran talvella 2012-2013 ja sai innostuneilta osallistujilta erittäin positiivista palautetta. Ilmoittautuminen molemmille kursseille Palmenian koulutuskalenterin kautta (helsinki.fi/palmenia/koulutus). Kurssit ovat Opetushallituksen rahoittamia ja osallistujille maksuttomia.

Tammikuussa 2013 järjestetään myös opettajien työpaja Hyytiälän metsäasemalla, jossa osallistujat perehtyvät oikeaoppisiin lumensyvyysmittauksiin ja sovitaan talvena 2013-2014 suoritettavasta GLOBE lumensyvyysmittauskampanjan yksityiskohdat. Lumikampanjaan osallistuvien koulujen kesken arvotaan voittaja ja lumimittaukset tehnyt luokka kutsutaan tutustumiskäynnille USA:n suurlähetystön energiatehokkaaseen Innovation center rakennukseen!

Kesällä 2013 Opetushallitus myönsi Helsingin yliopiston Viikin Normaalikoululle tukea kansainväliseen GLOBE-toimintaan ja toivomme mahdollisimman monen vanhan ja uuden GLOBE-koulun innostuvan mukaan. Viikissä tukea tullaan käyttämään lukion puolella uuden, monitieteisen ilmastokurssin suunnitteluun ja toteutukseen. Lisäksi kehitetään GLOBE-hengessä jo olemassaolevia toimintoja, mm. 7-luokkalaisten luontopäivää ja koko koulua koskevaa LUMA-viikkoa. Myös opetusharjoittelijoita otetaan mukaan GLOBE- 
toimintaan, jolloin tietoisuus hankkeesta siirtyy luontevasti seuraaville opettajavuosikerroille.

GLOBE-ympäristöprojektin, Lukion GLOBE-Viikki -kurssilla ilmastoa pyritään tarkastelemaan useasta näkökulmasta: luonnontieteellistä perustaa täydennetään esimerkiksi opiskelijoiden tekemällä asennegallupilla sekä ympäristöfilosofin vierailulla. Keskeisinä aihepiireinä ovat ilmakehä, ilmasto ja sen tutkiminen, ilmaston muutos, kaupunki-ilmasto, sää, lumitutkimus, pilvibongaus ja mahdollisesti kasviruudun seuranta. Kurssiin sisältyy lähiopetusta sekä mittauksia koululla ja kaupungilla, vierailijoiden pitämiä luentoja ja vierailukäyntejä ilmastoa tutkiviin laitoksiin. Lisäksi opiskelijat tekevät itsenäisesti nettiin laitettavan esityksen. Kurssi toteutetaan tammikuussa 2014 ja se toteutetaan hajautettuna jatkuen kevään ajan.

Elokuussa 2013 GLOBE:laiset kutsuttiin tutustumaan lumikampanjaan ja USA:n suurlähetystön energiatehokkaaseen Innovation center -rakennukseen.

Suomenkieliset GLOBE-verkkosivut uudistetaan syksyn aikana. Ne löytyvät Suomen GLOBE-sivut www.globe-europe.org-sivuston maavalikosta.

Lisätietoja:

Suomen GLOBE-maakoordinaattori Taina Ruuskanen (taina.ruuskanen@helsinki.fi) www.globe.gov 
RIUTTANEN \& RUUSKANEN 